\title{
Phytochemicals with antifungal properties: Cure from nature
}

\author{
Amal A. M. Elgharbawy ${ }^{1 \star}$, Nurhusna Samsudin ${ }^{1}$, Farah Fadwa Benbelgacem², Yumi Zuhanis Has-Yun Hashim¹, \\ Hamzah Mohd. Salleh ${ }^{1}$ and Jacinta Santhanam ${ }^{3}$ \\ ${ }^{1}$ International Institute for Halal Research and Training (INHART), International Islamic University Malaysia, P.O. Box 10, \\ 50728 Kuala Lumpur, Malaysia. \\ ${ }^{2}$ Department of Biotechnology Engineering, International Islamic University Malaysia, P.O. Box 10, 50728 Kuala Lumpur, \\ Malaysia. \\ ${ }^{3}$ Biomedical Science Program, Faculty of Health Sciences, Universiti Kebangsaan Malaysia, Jalan Raja Muda Abdu \\ Aziz, 50300 Kuala Lumpur, Malaysia. \\ Email: amal.elgharbawy@gmail.com
}

Received 12 August 2019; Received in revised form 8 January 2020; Accepted 2 March 2020

\begin{abstract}
Aims: The exploration of natural products with innovative uses is dynamic and expanding rapidly. Medicinal plants have fascinated many researchers that subsequently lead to research publications highlighting plant extracts with wide range of secondary metabolites such as flavonoids, alkaloids, glycosides, quinones, terpenoids, tannins and saponins that exhibit antimicrobial activities and disease control. The concentration of these bioactive compounds in each plant species varies based on the pathosystem and environmental conditions. This study aims to uncover the various types of phytochemicals with antifungal properties.

Methodology and results: Seven categories of plant-based antifungal compounds were reviewed, which are terpenoids, saponins, phenolic compounds, coumarins, alkaloids, essential oils and peptides, with examples and structures of some available compounds. The mechanism of action of each category of phytochemical was discussed. Also, the impact of some compounds was explained and elaborated.

Conclusion, significance and impact of study: It is of a great importance to explore natural plant fighters against fungal infection. Those active plant components do not only have antifungal properties, but they also help in the healing process and some even exhibit anticancer activities. The development and knowledge of antifungal activities from plant extracts have the potential for applications in antifungal therapy. Since the exact description of how antifungal compounds function in the human body is still unclear more studies are required to unveil phytochemicals' properties and to elucidate their effects on living cells.
\end{abstract}

Keywords: Antifungal, phytochemical, secondary metabolite, natural products, minimum inhibitory concentration (MIC)

\section{INTRODUCTION}

A fungus belongs to eukaryotic organisms that embrace both multicellular and unicellular microorganisms such as molds and yeasts, as well as mushrooms. Fungi are classified as a kingdom, separated from other eukaryotic kingdoms of animals and plants. Pathogenic fungi cause diseases in humans and other organisms (Baxi et al., 2016). Fungi are ubiquitous microorganisms that can be found everywhere. When airborne, fungi take the form of spores, mycelia and hyphal fragments. When inhaled, such particles contribute to health effects in human, including several diseases. Common fungi include Cladosporium, Epicoccum and Alternaria, to name a few. Moreover, fungi that are associated with decay or indoor water damage include Aspergillus, Penicillium,
Chaetomium and Stachybotrys (Baxi et al., 2016) and few species that are pathogenic to human. Candida, Aspergillus and Cryptococcus are pathogens that normally caused infection to humans (Karkowska-kuleta et al., 2009). However, fungi play an important role in an ecosystem and significantly contribute to biological stability such as in the form of insect symbionts, mycorrhizae and lichens. Several types of fungi break down organic biomaterials such as complex carbohydrates and contaminants such as petroleum, xenobiotics and hydrocarbons. Thus, fungi play a vital part in the carbon cycle (Gulis et al., 2009).

There are two general groups of fungal pathogens, which are primary and opportunistic pathogens. Primary pathogens usually develop an environmental reservoir and infect individuals that encounter with a large dosage 
of the fungi from the environment. Opportunistic pathogens provoke disease in hosts when their systemic immunity has been innately dysfunctional, damaged, or impaired. Fungal pathogenesis's mechanisms are not well-recognized as bacterial pathogens. Few fungi are proficient pathogens in contrast to bacteria (Burik and Magee, 2001).

Candida albicans is the foremost fungal pathogen to humans. The infections with Candida are severe, particularly for individuals with weak immune defense. $C$. albicans can form highly ordered biofilms, microbial colonies that are enclosed by extracellular matrix and they are attached to a solid surface (Chandra et al., 2001). The formation of $C$. albicans biofilms is troublesome to medical practitioners, where the biofilm is normally found on an implanted medical device (Uppuluri and Lopez Ribot, 2017). It may act as a reservoir for the pathogenic cells that are resistant to host immune system and drugs that may lead to invasive systemic infections of tissue, organ and infect almost all inner organs, including lungs, kidney, heart, liver, spleen and brain, causing fungemia and lifethreatening septicemia (Karkowska-kuleta et al., 2009). Over $50 \%$ of the central venous catheters are infected by C. albicans biofilm with approximately 100,000 death and excess of $\$ 6.5$ billion in expenditure annually in the United States (Fox and Nobile, 2013).

The development of $C$. albicans biofilm undergoes four distinct phases. The formation of a biofilm begins with the seeding step, where the cells adhere to a solid surface to form a basal layer of anchoring cells. This phase normally takes approximately $60-90 \mathrm{~min}$. Next, is the early-stage of filamentation, where the cells start to proliferate. Following this is the formation of a complex network that consists of several layers of cells such as hyphal cells, pseudohyphal cells and round cells enclosed in an extracellular matrix. This stage is called a biofilm maturation stage, which typically takes $24 \mathrm{~h}$ to form. The last stage is the dispersal stage, where the round cells detach from the biofilm to seed a new site (Douglas, 2003).

At present, the exploration of natural products with innovative uses are dynamic and expanding rapidly. Medicinal plants have fascinated many researchers that subsequently lead to research publications highlighting plant extracts with wide range of secondary metabolites such as flavonoids, alkaloids, glycosides, quinones, terpenoids, terpenoids, tannins and saponins that exhibit antimicrobial activities and disease control. Figure 1 shows the number of publications on antifungal, phytochemicals, essential oils and plant extract in the period 2008- 2019. The concentration of these bioactive compounds in each plant species varies based on the pathosystem and environmental conditions. A medicinal plant is in which one or more of its parts, contains functional phytochemical, which can be isolated and applied either for medicinal treatment or as a drug constituent (Sofowora et al., 2013). To date, plant species of Allium sativum L. (garlic), Glycyrrhiza glabra L. (licorice) and Aloe vera (L.) Burm f. (aloe) are known to have bioactive natural products with significant antifungal activities (Sales et al., 2016). This review paper aimed to uncover various plants with antifungal properties. It also reveals the mechanism of actions of several groups of antifungal compounds and their effect at the cellular level.

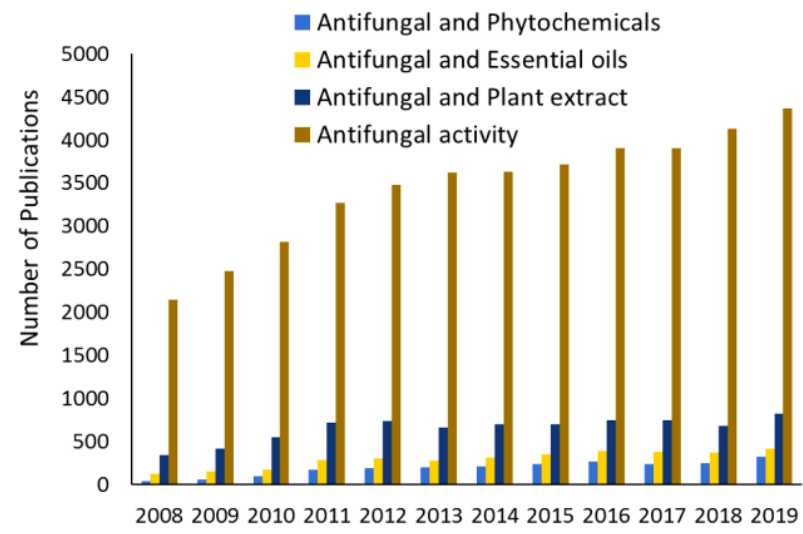

Year of Publication

Figure 1: Number of publications in 2008 to 2019 duration through Scopus search, using the keywords: "antifungal + phytochemicals", "antifungal + essential oils", "antifungal + plant extract" and "antifungal activity", as of $21^{\text {st }}$ May 2020.

\section{SECONDARY METABOLITES WITH ANTIFUNGAL ACTIVITY}

\section{Terpenoids}

\section{What are terpenoids?}

Terpenoids are secondary metabolites that can be isolated from natural sources such as plants, microorganisms, animals, insects, marines and endophytes. Terpenoids compose of more than 40,000 variations to date, which are still being explored. Most of the terpenoids variations with biologically active properties are useful as therapeutics and preventive agents for several diseases, including cancer. Terpenoids exhibit antifungal, antimicrobial, antiviral, antiparasitic, antispasmodic, antiallergenic, anti-inflammatory, immunomodulatory and antihyperglycemic properties (Thoppil and Bishayee, 2011). Meanwhile, there are some terpenoids variations that are toxic and have a severe impact on the nervous system and the functional ability of the human body (Mbaveng et al., 2014).

Terpenoids are classified based on the number of $\mathrm{C}_{5} \mathrm{H}_{8}$ isoprene units (2-methylbuta-1,3-diene) and the structural organization of carbons. The single isoprene unit accounts for most classes of terpenoids. Hemiterpenoids contains five carbons and one unit of isoprene. The subsequent classes increase by five carbons at a time and one isoprene unit, starting with monoterpenes. The backbone and structure of terpenoids reported in this review are shown in Figure 2. 
<smiles>C=CC(=C)C</smiles>

Isoprene (unit) Building block<smiles>C=C1CCCC(C)(C)C2C=C(C)CCC12</smiles>

Sesquiterpenes<smiles>CC1(C)CCC[C@@]2(C)[C@H]1CC=C(C=O)[C@@]2(C)C=O</smiles>

Warburganal<smiles>CC1C(=O)O[C@]23C(C)CC[C@@](C)(O[C@@H]12)[C@H]3C</smiles>

Arteannuin B<smiles></smiles>

Parthenolide<smiles>CC(C)[C@H]1CC[C@H]2[C@@H]3CC[C@H]4[C@](C)(CC[C@]5(C)C(C)(C)CCC[C@]45C)[C@]3(C)CC[C@@]21C</smiles>

Triterpinoid<smiles>C=C1[C@H](C)CC[C@]2(C)[C@@H]1CC=C(C=O)[C@]2(O)C=O</smiles>

Muzigadial<smiles>C[C@H]1CCC2[C@@H](C)C(=O)OC3C[C@]4(C)CCC1[C@]32OO4</smiles>

Artemisinin<smiles>C=C1C(=O)O[C@H]2C1CC[C@@]1(C)OC1CCC2(C)C</smiles>

1,10-Epoxyparthenolide

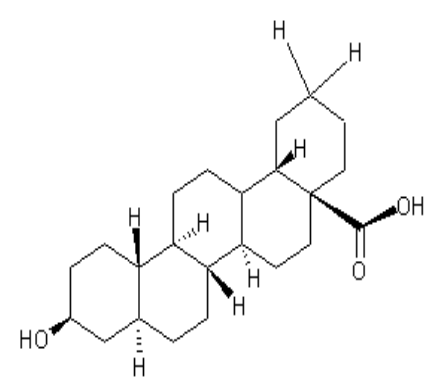

Oleanolic acid<smiles>Cc1ccc(C(C)C)c(O)c1</smiles>

Thymol<smiles>Cc1ccc(C(C)C)cc1O</smiles>

Carvacrol 


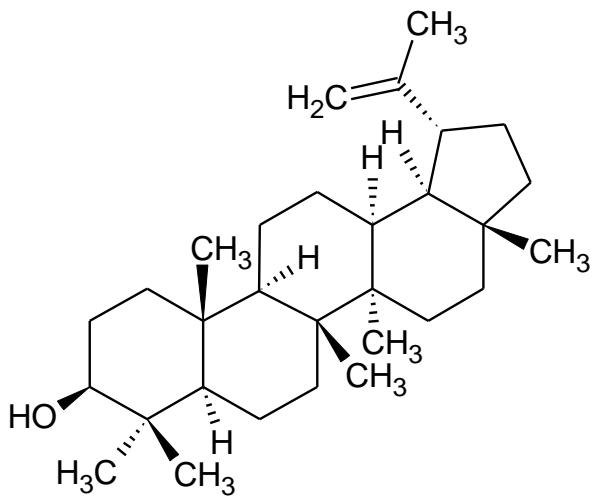

Lupeol<smiles>CC[C@H](/C=C/[C@@H](C)[C@H]1CC[C@H]2[C@@H]3CC=C4C[C@@H](O)CC[C@]4(C)[C@H]3CC[C@@]21C)C(C)C</smiles>

Stigmasterol<smiles>CC[C@H](CC[C@@H](C)[C@H]1CC[C@H]2[C@@H]3CC=C4C[C@@H](O)CC[C@]4(C)[C@H]3CC[C@@]21C)C(C)C</smiles>

$\beta$-sitosterol<smiles>C=C1C(=O)O[C@H](CC)/C=C(\C)CC/C=C\1C</smiles>

Costunolide<smiles>Cc1ccc(C(C)C)cc1</smiles>

$P$-cymene 


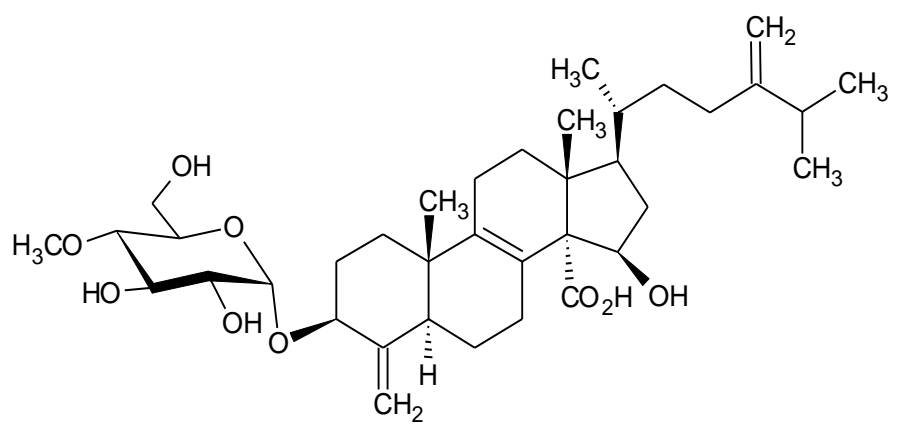

Ascosteroside

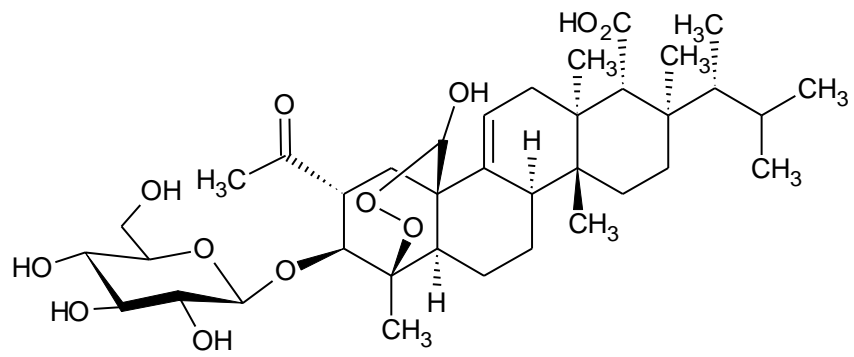

Enfumafungin<smiles>CC(CCC(O)C(C)(O)CO)C1CCC2(C)C3=C(CCC12C)C1(C)CCC(OC(=O)CCC(=O)O)C(C)(C)C1CC3</smiles>

Arundifungin

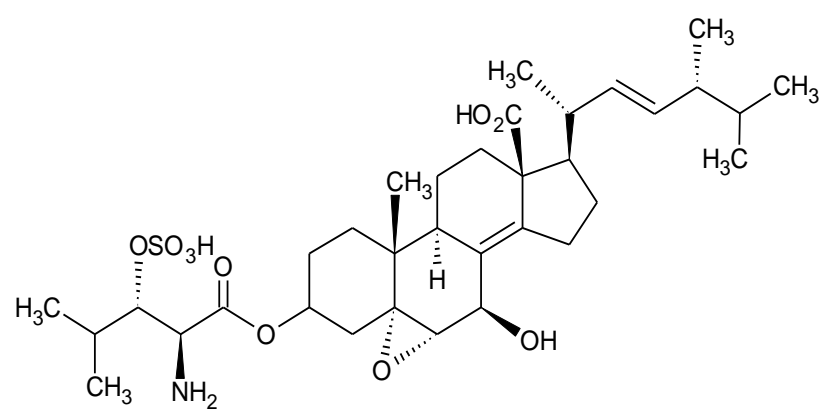

Figure 2: The isoprene building block of terpenoids and chemical structures of some terpenoids. 
Most sesquiterpenes $\left(\mathrm{C}_{25} \mathrm{H}_{40}\right)$ have anti-plasmodial and antimicrobial activities while some have antifeedant, anticancer, anti-mycotoxigenic, antioxidant, antiinflammatory, anti-protozoal and cytotoxic activities. Costunolide, parthenolide and its derivative $(1,10$ epoxyparthenolide) from sesquiterpenes family were recognized for their antimicrobial activities against Helminthosporium spp. Significant antifungal activities were also detected by warburganal and muzigadial, against Sclerotinia libertiana, Candida utilis, and Saccharomyces cerevisiae (Mbaveng et al., 2014).

\section{Mechanism of action}

The main key phytochemicals to determine the reactivity of terpenoids are thymol and carvacrol that are abundant in thyme oil. Thymol normally hinders the formation and viability of hyphae and promotes morphological alterations in the envelope of $C$. albicans. Furthermore, in a dosedependent manner, thymol express anti-inflammatory effects by depriving the expression of the proinflammatory mediators' gene. Terpenoids also target mitochondria resulting in significant death of $S$. cerevisiae, especially in the case of lupeol. Data clearly shows that terpenoids reduced the mitochondrial content, thus modified the level of reactive oxygen species (ROS) and ATP generation. It is also reported that triterpenoid possesses more potent antifungal activity as compared to the tetraterpenoid (Haque et al., 2016).

The hydrophobic nature of terpenoid phenols allow infusion into the lipid membrane. However, $p$-cymene, a precursor of carvacrol, has a higher partition coefficient for lipid membranes; therefore, hydrophobicity alone does not ensure its antifungal action. Instead, the hydroxyl group contributes to the function. The delocalized electron in carvacrol facilitates the dissociation of $\mathrm{H}^{+}$from the $\mathrm{OH}$ group that resulted in $\mathrm{H}^{+}$and monovalent cations such as $\mathrm{K}^{+}$migrate across membranes by carvacrol and eliminate $\mathrm{pH}$ and $\mathrm{K}^{+}$gradients across cell membranes. Besides, carvacrol also depolarizes bacterial cell membranes. However, that mechanism does not explain the transient $\mathrm{Ca}^{2+}$ bursts associated with carvacrol. It might, therefore, be that the effects on membrane expansion and fluidity that cause the opening of ion channels followed by their rapid desensitization (Rao et al., 2010). To sum up, terpenoids may act in four ways; (1) the formation of hyphae (2) reducing gene expression (3) mitochondrial dysfunction (Ludwiczuk et al., 2017), (Haque et al., 2016) and (4) depolarization of membranes and calcium ion stress (Rao et al., 2010).

\section{Antifungal activity of terpenoids}

Terpenoids in Cannabis have a variety of effects, such as antifungal and antimalarial activity. Terpenoids from hash oil obtained from drug cultivars of Cannabis displayed an antimicrobial effect that was greater than essential oil derived from fiber cultivars (Hazekamp et al., 2010). Terpenoid phenols carvacrol, thymol, and eugenol, which are the major components of oregano extract, have a potent antifungal activity of their own. Besides, terpenoid phenols are efficacious not only on planktonic cells but also on biofilms of $C$. albicans that are resistant to many antifungal drugs (Rao et al., 2010). Among all terpenoid phenols, carvacrol exhibited the strongest antifungal activity against $C$. albicans biofilms, with a minimum inhibitory concentration, MIC of $<0.03 \%$. Aside from $C$. albicans, the terpenoid phenols were also able to inhibit biofilms of several other strains of Candida, including $C$. glabrata, and C. parapsilosis. (Abdel-Massih et al., 2010). Antifungal fractions derived from the chloroform extract of Artemisia annua afforded two cadinane derivatives (arteannuin B and artemisinin), oleanolic acid, $\beta$-sitosterol, stigmasterol. arteannuin $\mathrm{B}$, a main sesquiterpenoid in $A$. annua, showed antifungal activity against one human ( $C$. albicans, MIC: $100 \mu \mathrm{g} / \mathrm{mL}$ ) and four plant pathogenic fungi (Gaeumannomyces graminis var. tritici, Rhizoctonia cerealis, Gerlachia nivalis and Verticillium dahliae, MICs: $150,100,150$ and $100 \mu \mathrm{g} / \mathrm{mL}$, respectively) (Tang et al., 2000). Terpenoids isolated from sunflower have also shown antifungal activities towards $V$. dahliae and $S$. sclerotiorum as they inhibited the hyphal growth (Picman et al., 1990). Ascosteroside, ergokonin A, arundifungin, and enfumafungin were reported as novel natural products. There is a possibility to develop an oral antifungal agent by the action that inhibits $(1,3)-\beta-D$ glucan synthase.

The promising antifungal properties of terpenoids were comparable to the commercial compounds, MK-0991 and L-733560 (antifungal agents). Moreover, the four terpenoids (ascosteroside, ergokonin $\mathrm{A}$, arundifungin and enfumafungin) preferentially inhibited various pathogenic Candida and Aspergillus strains. The antifungal spectrum, the change in morphology, and the antagonism of antifungal activity by sorbitol, for instance, suggested that terpenoids disrupted the construction of glucan fungal cell wall (Onishi et al., 2000).

\section{Saponins}

\section{What are saponins?}

Saponins are phytochemicals that produce foam (soap properties) when dissolved in water. Saponins are glycosides comprising of an aglycone (sterol or common triterpene) unit linked to one or more carbohydrate chains (sugar) as shown in Figure 3. The most common saponins are triterpenoid saponins that contain a hydrophilic part at one end separated from the lipophilic or hydrophobic part at the other. Steroidal saponins are normally found in the monocotyledons. Natural sources of saponins are oats, asparagus, spinach, soy legumes, beans and peanuts, and tea (Bone and Mills, 2013). The fundamental role of saponins in plants is protection against the attack of pathogens and pets. These molecules have high commercial value that has been used as drugs, foaming agents, sweeteners, taste modifiers and cosmetics (MertTürk, 2006). 


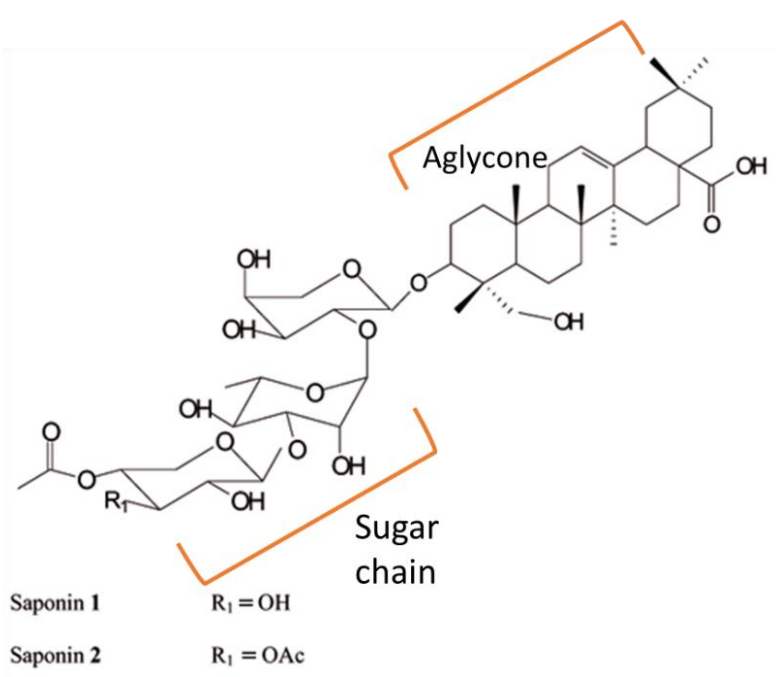

Saponin<smiles>OC(Cn1cncn1)(Cn1cncn1)c1ccc(F)cc1F</smiles>

Fluconazole

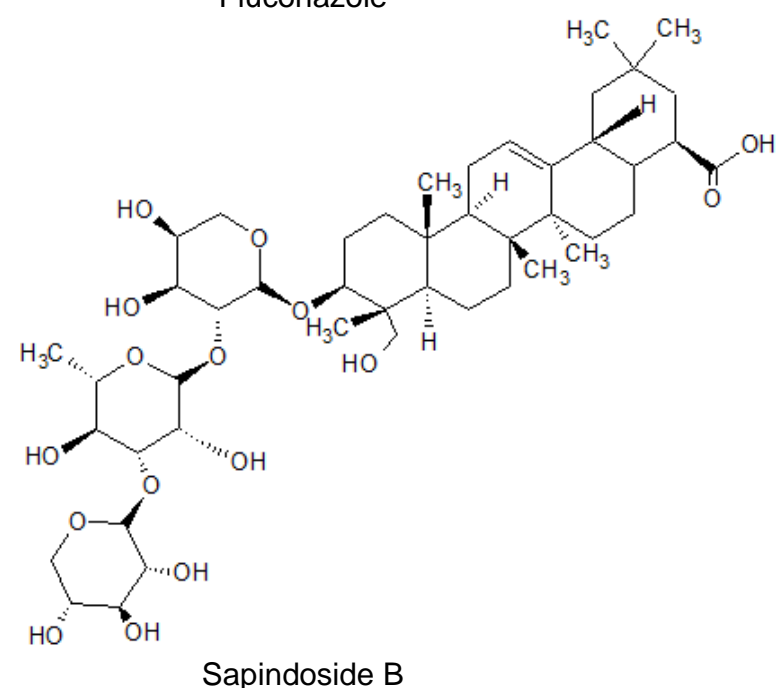<smiles>CC1(C)CCC2(C(=O)O)CC[C@]3(C)C(=CCC4C(C)(C(=O)O)C(OC5OC(CO)C(O)C(O)C5O)C(O)C[C@]43C)C2C1</smiles>

Medicagenic acid 3-O-beta-D-glucopyranoside

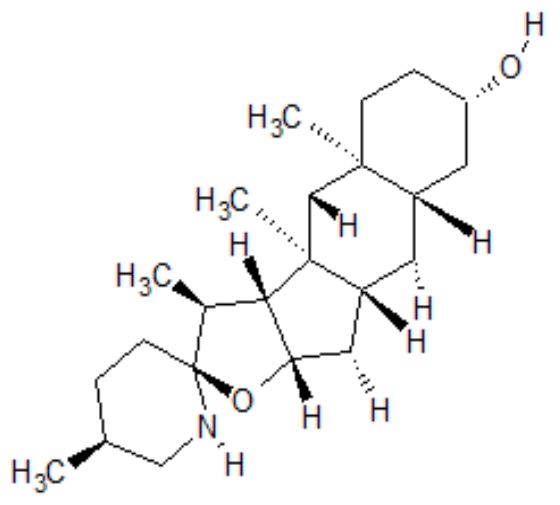

Tomatidine

Figure 3: Structure of saponins reported in this review. Reproduced with permission from (Tsuzuki et al., 2007). 


\section{Mechanism of action}

Based on the literature, spirostanol framework and the number of oligosaccharide residue attached at C-3 of aglycone appear closely associated with antifungal effects of steroid saponins (Zhang et al., 2006). Saponins may damage the cell membrane and cause cellular materials to leach out, which ultimately leads to cell death (Mshvildadze et al., 2006). For example, an antimycotic saponin from alfalfa root (medicagenic acid 3-O-beta-Dglucopyranoside), formed stable complexes with ergosterol, which resulted in lethal leakage of ions out of the yeast cells (Polacheck et al., 1991). The cell membrane of $C$. albicans was severely destroyed by fluconazole (saponin) from Tribulus terrestris $L$ (Zhang et al., 2006). Tea polyphenols (TP) and tea saponin (TS) and their combination were investigated against Rhizopus stolonifer. The two compounds significantly induced the production of $\mathrm{H}_{2} \mathrm{O}_{2}$, leading to membrane lipid peroxidation, which resulted in increment of the cell membrane permeability and leakage of soluble sugar, soluble protein and $\mathrm{K}^{+}$. Saponins have also destroyed the structure of the hyphal cell. It is concluded that TP, TS and their combination inhibited the $R$. stolonifer growth through inducing the production of $\mathrm{H}_{2} \mathrm{O}_{2}$, resulting in the oxidative damage of the cell membrane and leakage of intracellular materials (Jiang et al., 2015). The antifungal and antiparasitic activities of tomatidine (a saponin produced by tomato; Solanum lycopersicum) against Saccharomyces cerevisiae and some parasites, such as Leishmania amazonensis and Phytomonas serpens, have been reported. It was revealed that tomatidine induced a perturbation of ergosterol biosynthesis through the inhibition of Erg6 (C-24 sterol methyltransferase) activity and Erg4 (C-24 sterol reductase) activity (Dorsaz et al., 2017).

\section{Antifungal activity of saponin}

Saponin extract from rhizomes of Dioscorea panthaica Prain et Burk (Huangshanyao saponin extract, HSE) was tested against $C$. albicans. HSE inhibits the planktonic growth and biofilm formation and development of $C$. albicans at a concentration of $16-64 \mu \mathrm{g} / \mathrm{mL}$. Furthermore, inhibitory activities against extracellular exopolysaccharide (EPS) production and ROS production in preformed biofilms could be inhibited by $64-256 \mu \mathrm{g} / \mathrm{mL}$ of $\mathrm{HSE}$. Cytotoxicity against human was also tested with Chang's liver cells, but the cytotoxicity was low with a half-maximal inhibitory concentration (IC50) of about $256 \mu \mathrm{g} / \mathrm{mL}$ (Yang et al., 2018).

The antifungal activity of Sapindus mukorossi extract was tested against Venturia inaequalis and Botrytis cinerea - two important fungal pathogens worldwide. The spray extract with a concentration of $(1 \% \mathrm{v} / \mathrm{v})$ significantly reduced $V$. inaequalis symptoms and sporulation (99\%) on apple seedling leaves $(P \leq 0.05)$. The applications of $1 \% \mathrm{v} / \mathrm{v}$ of the extract reduced the disease severity of $B$. cinerea on grapes on average by $63 \%$. The saponins identified were sapindoside B (hederagenin- pentosylhexoside), and oleanolic acid- hexosyldeoxyhexosyl-hexoside (Porsche et al., 2017).

\section{Phenolics}

\section{What are phenolic compounds?}

Natural phenolic compounds are secreted by plants and microorganisms. They are characterized by their low molecular weight with at least one phenolic group. They are the secondary metabolites produced by the plant within their ordinary development and they are reproduced as well under pressure conditions, for example, ultraviolet and incision (Shi et al., 2003). Phenolic compounds are standout amongst the most famous phytochemicals; they are of extensively significant in terms of physiology and morphology in plants. These compounds assume a vital job in development and generation, giving insurance against pathogens and predators, other than contributing towards the taste and the color of the plant fruits. These compounds are derived from the pentose phosphate, shikimate, and phenylpropanoid tracks in plants (Balasundram et al., 2006). Phenolic acids, flavonoids, tannins, stilbenes, curcuminoids, coumarins, lignans, quinines and so forth are phenolic compounds isolated from the herbs of medical benefits and dietary plants (Huang et al., 2009).

\section{Mechanism of action}

One of the proposed mechanisms for antifungal agents is their binding to membrane ergosterol. To determine whether the phenolic extract of ethyl acetate fraction from Cochlospermum regium (mart. Et. Schr.) Pilger roots bind to the fungal membrane sterol, the MIC was determined with and without the addition of exogenous ergosterol. MICs values will be higher with the addition of fungal sterol if the activity was caused by binding to ergosterol. An increase at MIC of Candida krusei was induced, but no change was detected with C. glabrata, C. albicans and $C$. tropicalis. This is a piece of evidence of the binding of this phenolic compound to the membrane (Carvalho et al., 2018). Two mechanisms could be involved in this process: (i) binding to membrane ergosterol forming pores in this structure (Campoy and Adrio, 2017), or (ii) inhibition of enzymes involved in the synthesis of ergosterol, which reduces the content of that macromolecule (Ahmad et al., 2015). Phenolic acids, such as ferulic and gallic acids, are known to affect the cell membrane of bacteria, which results in changes in the hydrophobicity and charge of the cell surface, causing leakage of cytoplasmic content (Borges et al., 2013). A similar effect has been proposed for the caffeic acid derivatives on Candida cytoplasmatic membrane. Mode of action of several phenolic compounds have provided some clues to infer the mechanism of phenolic acids. For instance, curcumin, isoquercetin and lariciresinol can damage the $C$. albicans cell membrane. However, methyleugenol and eugenol significantly reduced the biosynthesis of ergosterol in 
Candida and thus, affected the cell membrane (Ahmad et al., 2015). Few studies have explained about other possible pathways of phenolic acid mechanism against Candida. For instance, isocitrate lyase was inhibited in $C$. albicans after treatment with caffeic acid, rosmarinic acid and apigenin (Cheah et al., 2014), (Figures 4 and 5).

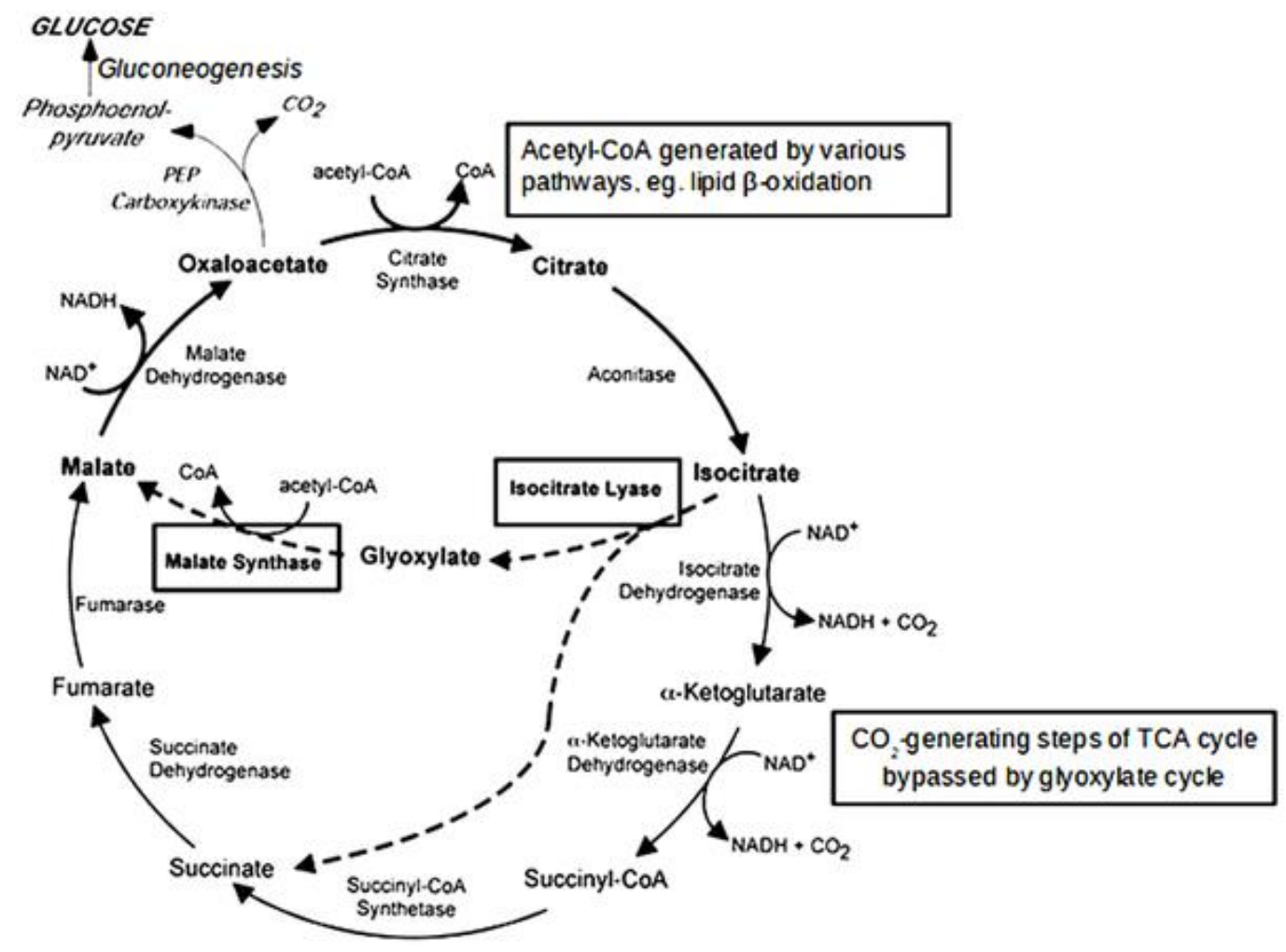

Figure 4: Tricarboxylic acid (TCA) cycle (black arrows) and glyoxylate cycle (dashed arrows). Adapted from Cheah et al. (2014). Creative Commons Attribution License.<smiles>Oc1cc(O)c2c(c1)O[C@H](c1ccc(O)c(O)c1)C(O)C2</smiles>

Catechin<smiles>O=c1cc(-c2ccc(O)c(O)c2)oc2cc(O)cc(O)c12</smiles>

Luteolin 
Malays. J. Microbiol. Vol 16(4) 2020, pp. 323-345

DOI: http://dx.doi.org/10.21161/mjm. 190551<smiles>O=c1c(O)c(-c2ccc(O)c(O)c2)oc2cc(O)cc(O)c12</smiles>

Quercetin<smiles>O=c1cc(-c2ccccc2)oc2cc(O)c(O)c(O)c12</smiles>

Baicalein<smiles>COc1cc(/C=C/C(=O)O)ccc1O</smiles>

Ferulic acid

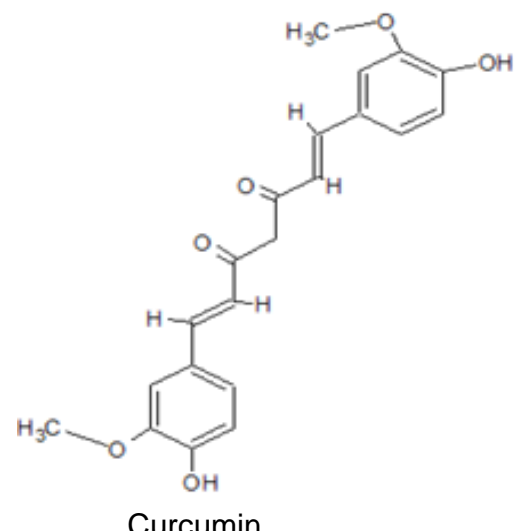<smiles>O=C(O)c1cc(O)c(O)c(O)c1</smiles>

Gallic acid<smiles>COc1c(O)cc(O)c2c(=O)cc(-c3ccccc3)oc12</smiles>

Wogonin<smiles>O=C(O)/C=C/c1ccc(O)c(O)c1</smiles>

Caffeic acid<smiles>[CH]OC[C@H]1O[C@@H](OC2=C(c3ccc(O)c(O)c3)OC3=CC(O)=CC(O)C3C2=O)[C@H](O)[C@@H](O)[C@@H]1O</smiles>

Isoquercetin 
Malays. J. Microbiol. Vol 16(4) 2020, pp. 323-345

DOI: http://dx.doi.org/10.21161/mjm. 190551<smiles>COc1cc(C[C@@H]2CO[C@@H](c3ccc(O)c(OC)c3)[C@H]2CO)ccc1O</smiles>

Lariciresinol<smiles>C=CCc1ccc(O)c(OC)c1</smiles>

Eugenol<smiles>O=c1cc(-c2ccc(O)cc2)oc2cc(O)cc(O)c12</smiles>

Apigenin

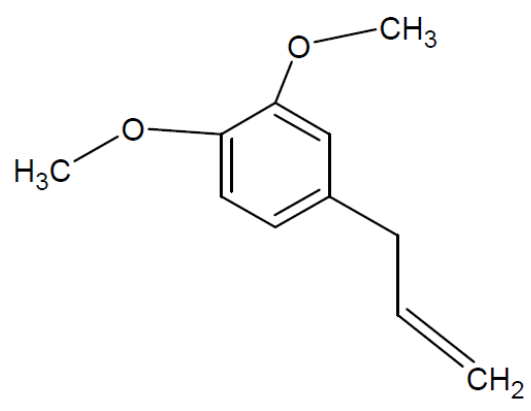

Methyleugenol<smiles>COc1cc(/C=C/C(=O)O[C@H](Cc2ccc(O)c(O)c2)C(=O)O)ccc1O</smiles>

Rosmarinic acid

Figure 5: Structures of phenolic compounds reported in this review. 


\section{Antifungal activity of phenolic compounds}

Several studies have been performed in order to evaluate the antifungal potential of polar extracts from plant origin, which are enriched in phenolic compounds, such as aqueous, ethanolic, methanolic, hydroalcoholic, acetone and dimethyl sulfoxide (DMSO). The most studied preparations are the aqueous extracts, followed by methanolic and ethanolic extracts (Martins et al., 2015). The aqueous phenolic extract from Fragaria virginiana Duchesne, Epilobium angustifolium L. and Potentilla simplex Michx. demonstrated strong antifungal potential. Fragaria virginiana had some degree of activity against all of the fungal pathogens; Alnus viridis DC., Betula alleghaniensis Britt. and Solidago gigantea Ait. (Webster et al., 2008). Alves et al. (2014) evaluated the antifungal effect of catechin, luteolin, quercetin, and gallic acid, phenolic compounds identified from flowers of North-Eastern Portugal, against Candida planktonic and biofilm cells. MIC values demonstrated that gallic acid presented the highest effect against all Candida species. Catechin showed a similar effect against $C$. albicans American Type Culture Collection (ATCC) 90028 cells. In addition, gallic acid and quercetin had demonstrated only a minimal effect against Candida species biofilms (Alves et al., 2014). Zabka and Pavela tested the antifungal efficacy of 21 phenolic components of essential oils and plant substances against these filamentous fungi; Fusarium, Aspergillus and Penicillium genera. Thymol and carvacrol were evaluated as the most effective. The $\mathrm{MIC}_{50}$ values for thymol ranged from 30 to $52 \mu \mathrm{g} / \mathrm{mL}$. The $\mathrm{MIC}_{100}$ values for thymol ranged from 76 to 255 $\mu \mathrm{g} / \mathrm{mL}$, respectively. For carvacrol, the $\mathrm{MIC}_{50}$ values ranged from 37 to $76 \mu \mathrm{g} / \mathrm{mL}$, and the $\mathrm{MIC}_{100}$ ranged from 131 to $262 \mu \mathrm{g} / \mathrm{mL}$ (Zabka and Pavela, 2013). Fungal culture in the presence of various concentrations of baicalein extracted from Ou-gon extracts showed antifungal activity against $T$. rubrum, Trichophyton mentagrophytes, Aspergillus fumigatus, and Candida albicans. Wogonin obtained from the same plant exhibited antifungal activity towards all fungi except $C$. albicans (Da et al., 2019).

\section{Coumarins}

\section{What is coumarins?}

From their name, coumarins are derived from Coumarouna odorata plant; they are one of the benzopyrones which consist of benzene fused to $\alpha$ pyrone ring. Coumarins are numerous; around one thousand coumarins are present with abundance in angiosperms. They are found in over 150 different species of plants belonging to almost 30 different families. They are mainly secondary metabolites of plants and present in some microbes. In addition to their activity as an antioxidant, antiinflammatory, antifilarial, antiulcerogenic, trypanocidal, antibacterial, antitumor and antiHIV, coumarins have shown a strong antifungal activity (Montagner et al., 2008).

Coumarins are classified based on their structural diversity into four groups. Coumarin derivatives or called simple coumarins, consist of two rings and substituted on their $\mathrm{C} 7, \mathrm{C} 6$ and $\mathrm{C} 3$ positions by benzopyrone, hydroxyl, methoxy and aliphatic groups. The second group of coumarins is isocoumarin derivatives, formed by benzene rings and $\alpha$-isopirone and they have substituents in positions C3, C6, C7 and C8. They are isolated mainly from fungi: Artemisia, Aspergillus, Fusarium, Penicillium, Streptomyces and the few plants belonging to families: Compositae, Leguminosae and Myrtaceae. The third group is furanocoumarin derivatives, consist of coumarin ring coupled with the furan ring at the $\mathrm{C} 6-\mathrm{C} 7$ position (psoralen type) or in the C7-C8 position (angelicin type). Finally, the fourth group is pyrancoumarin derivatives, where the coumarin ring is condensed with pyran ring to form xanthyletin-type if the condensation is at the C6C7 position, or seselin-type if at the position C7-C8 (Tomasz Kubrak et al., 2017).

\section{Antifungal activity of Coumarins}

Osthole is a coumarin isolated from plants with therapeutic capacities like Angelica pubescens Cnidium monnieri, and Peucedanum ostruthium. Rhizoctonia solani, Phytophtora capsici, Botrytis cinerea, Sclerotinia sclerotiorum, and Fusarium graminearum are highly pathogenic fungi and osthole is used as a treatment against them due to its high antifungal activity spectrum. Psoralen, imperatorin, and ostruthin have the highest antifungal effectiveness of all the coumarins (Venugopala et al., 2013). In addition to the examples cited in Table 1, byosthol is a derivative of coumarin isolated from celery plants, which demonstrates activity against $R$. solani, $P$. capsici, $B$. cinerea, $S$. sclerotiorum and $F$. graminearum (Tomasz Kubrak et al., 2017). In Table 1, the two types of coumarins with antifungal activity are cited.

In Srinivasan and Sarada (2012), the antifungal activity of pyranocoumarin (PDP) available in Psoralea corylifolia was established. In addition to their capacity as an antifungal agent against Fusarium sp., the molecular docking analysis performed with the X-ray crystal structures of Tri101, trichothecene 3-Oacetyltransferase available in the Protein Data Bank proposed a hypothetical mechanism for antifungal activity against plant pathogen Fusarium $\mathrm{sp}$. The minimum inhibitory concentration of $1 \mathrm{mg} / \mathrm{mL}$ was detected for the PDP against $F$. oxysporum, $F$. moniliforme, and $F$. graminearum. The molecular docking has shown the affinity towards the target protein and by binding to the protein, it will inhibit the acetylation mechanism ending by fungi death. $C$. albicans exposition to coumarin within twenty-four hours has shown cell membrane and cell wall alteration, and 
Malays. J. Microbiol. Vol 16(4) 2020, pp. 323-345 DOI: http://dx.doi.org/10.21161/mjm. 19055

Table 1: Most effective coumarins with antifungal activity.

\begin{tabular}{|c|c|c|c|c|c|}
\hline $\begin{array}{l}\text { Type of } \\
\text { coumarin }\end{array}$ & Chemical structure & Example of coumarin & Plant of origin & Fungi target & Reference \\
\hline \multirow[t]{2}{*}{$\begin{array}{l}\text { Simple } \\
\text { coumarins }\end{array}$} & & Ostruthin & $\begin{array}{l}\text { Peucedanum } \\
\text { ostruthium }\end{array}$ & Saccharomyces cerevisiae & (Feuer, 1974) \\
\hline & & Osthole & $\begin{array}{l}\text { Angelica pubescens, } \\
\text { Cnidium monnieri, } \\
\text { and Peucedanum } \\
\text { ostruthium }\end{array}$ & $\begin{array}{l}\text { Rhizoctonia solani, } \\
\text { Phytophtora capsici, } \\
\text { Botrytis cinerea, } \\
\text { Sclerotinia sclerotiorum, } \\
\text { and Fusarium } \\
\text { graminearum }\end{array}$ & $\begin{array}{l}\text { (Wang et al., } \\
2010)\end{array}$ \\
\hline \multirow[t]{2}{*}{$\begin{array}{l}\text { Furano- } \\
\text { coumarins }\end{array}$} & & Imperatorin & $\begin{array}{l}\text { Glehnia littoralis, } \\
\text { Prangos pabularia, } \\
\text { Clausena ansium, } \\
\text { and Aegle marmelos }\end{array}$ & Saccharomyces cerevisiae & $\begin{array}{l}\text { (Kozioł and } \\
\text { Skalicka- } \\
\text { Woźniak, 2016) }\end{array}$ \\
\hline & & Psoralen & Psoralea corylifolia & $\begin{array}{l}\text { Fusarium oxysporum, } \\
\text { Fusarium moniliforme, } \\
\text { and Fusarium } \\
\text { graminearum }\end{array}$ & $\begin{array}{l}\text { (Srinivasan and } \\
\text { Sarada, 2012) }\end{array}$ \\
\hline
\end{tabular}


cytoplasmic volume decreases followed by structural disarrangement. However, the mode of function adopted by coumarin (1,2-benzopyrone) has yet to be depicted. Respiration and ergosterol synthesis dysfunctioning were the strategies adopted by silver (I)coumarin complexes against $C$. albicans whereby the exact mechanism targeted cytochrome $c$ synthesis disruption, which may also cause apoptosis (Srinivasan and Sarada, 2012). Jia et al. (2019) have studied the effects of coumarin on cell growth inhibition and strain viability reduction by experimenting and determining yeast apoptosis with phosphatidylserine (PS) externalization, DNA fragmentation, cytochrome $c$ release, and metacaspase activation. Their results explored the role of coumarin in PS exposure on the outer leaflet, DNA degradation and nuclear compaction, cytochrome $c$ release, and metacaspase activation, suggesting that coumarin induced apoptosis in $C$. albicans. Previous studies have demonstrated that coumarin damages $C$. albicans cells via pore formation in the fungal cell wall and seep of cytoplasmic contents and necrosis are phenomena adopted by coumarins and elaborated previously (Jia et al., 2019).

\section{Alkaloids}

\section{What are alkaloids?}

Deriving from amino acids and with a nitrogen atom in the heterocyclic ring, alkaloids are formed and considered as an important class of structurally diversified compounds. Alkaloid nomenclature is derived from the Arabic term al-qali, the plant from which soda was first isolated. Alkaloids cover roughly $20 \%$ of plant-based secondary metabolites and they exhibit antimicrobial, anticancer, narcotics, toxic substances and stimulant capacities. Nowadays, around 12,000 alkaloids are confined from various genera of the plant kingdom. This number makes this class of natural products biologically important (Kaur and Arora, 2015).

The examples of alkaloids acting as antifungal are numerous. The mode of their antifungal action is usually pleiotropic, where protein synthesis is inhibited, and the fungal DNA is intercalated or by boosting the development of fungi inhibitors. The first medically useful example of an alkaloid was morphine, isolated in 1805 from the opium poppy Papaver somniferum (Arif et al., 2009). Phenanthridine, an alkaloid isolated from Chelidonium majus exhibits antifungal activity against the clinical drug-resistant yeast isolates. Bisbenzylisoquinoline alkaloids such as cycleanine and cocsoline isolated from Albertisia villosa have antibacterial, antifungal, antiplasmodial activities in addition to cytotoxic potential related to these alkaloids (Kaur and Arora, 2015).

\section{Mechanism of action}

The two alkaloids; liriodenine methiodide (LMT), a methiodide salt of liriodenine, and eupolauridine 9591 (E9591), a synthetic analog of eupolauridine, exhibit their antifungal activities by interrupting mitochondrial iron-sulfur (Fe-S) cluster synthesis (Tripathi et al., 2017). There are several studies lending support to this theory. First, it was shown that both LMT and E9591 provoked a transcriptional response indicating iron imbalance. This induces the genes that are needed for iron uptake and for the maintenance of cellular iron homeostasis. Second, the analysis of a genome-wide fitness profile showed that mutant yeast cells that lack the iron homeostasis-related genes displayed hypersensitivity to LMT and E9591. Third, introducing LMT and E9591 to treat wild-type yeast cells resulted in cellular defects that imitated deficiency in mitochondrial Fe-S cluster synthesis, which include iron levels increment in mitochondria, respiratory function reduction, oxidative stress increment and loss of activity of Fe-S cluster enzymes. Another study by Dhamgaye et al. (2014) explored a plant alkaloid berberine (BER) for its antifungal potential. They have found a heat shock factor (HSF1) in TF mutant strains of $C$. albicans The mutant displayed collateral susceptibility towards drugs targeting cell wall (CW) and ergosterol biosynthesis and was highly susceptible to BER. The treatment with BER of Candida cells led to dysfunctional mitochondria, proven by the slow growth in nonfermentative carbon source and poor labeling with mitochondrial membrane potential sensitive probe (Dhamgaye et al., 2014). In summary, the suggested mechanism of alkaloids is causing a malfunction of the mitochondria, which causes a direct impact on the growth, respiratory activity and enzyme activity, hence, causes cell imbalance. The structures of alkaloids in this review are shown in Figure 6.

\section{Antifungal activity of alkaloids}

Singh et al. (2007) tested the antifungal properties of allosecurinine, an alkaloid extracted from Phyllanthus amarus Linn. (Family: Euphorbiaceae). The alkaloid inhibited mild spore germination of Curvularia lunata, Curvularia sp., Collectotrichum sp., C. musae and Heterosporium sp. at very low concentrations of allosecurinine (Singh et al., 2007). The ethanolic extract of the leaves of Alstonia scholaris contained seven monoterpenoid indole alkaloids. The isolated compounds were tested in vitro the antifungal potential against five species of fungi. The extract showed antifungal activity against two fungal strains; Gibberella pulicaris and Cercospora nicotianae (Wang et al., 2013). Six different species of Amaryllidaceae generated various alkaloids, which were studied by Miroslav et al. (2015) with respect to their anti-yeast activity. The analysis showed 25 alkaloids with 16 identified from their retention indexes, retention times and mass spectra. In the antimicrobial assay, isolates of 
<smiles>c1ccc2c(c1)cnc1ccccc12</smiles>

Phenanthridine

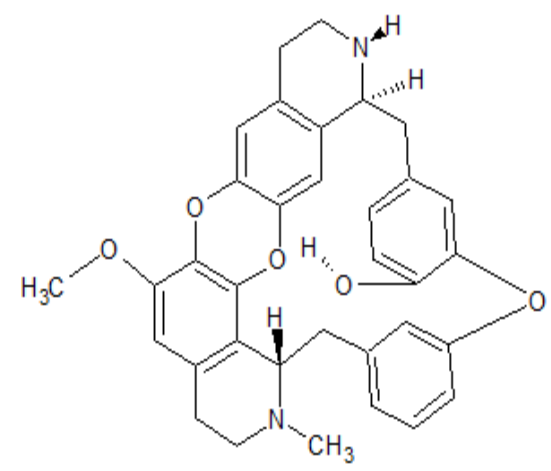

Cocsoline<smiles>C[n+]1ccc2cc3c(c4c2c1C(=O)c1ccccc1-4)OCO3</smiles>

Liriodenine methiodide<smiles>COc1ccc2cc3[n+](cc2c1OC)CCc1cc2c(cc1-3)OCO2</smiles>

Berberine

Figure 6: Structures of alkaloids reported in this review.

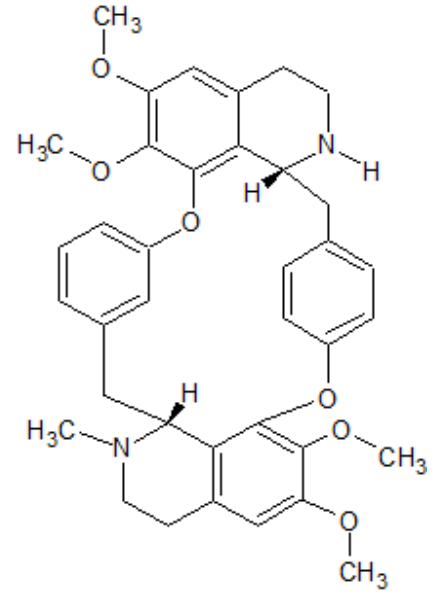

Cycleanine<smiles>O=C1C=C2C=C[C@H]3C[C@]2(O1)[C@H]1CCCCN31</smiles>

Allosecurinine<smiles>c1ccc2c(c1)-c1nccc3ccnc-2c13</smiles>

Eupolauridine 
the human pathogenic yeasts Candida albicans, $C$. glabrata, C. dubliniensis and Lodderomyces elongiosporus were tested. The six extracts, together with 19 Amaryllidaceae alkaloids showed promising anti-yeast properties although no antibacterial activity was detected. Among the alkaloidal extracts, Narcissus jonquilla cv. Baby Moon had the most effective antiyeast, with minimal and average MIC values of 128 and $192 \mu \mathrm{g} / \mathrm{mL}$, respectively, followed by Leucojum aestivum, Narcissus poeticus var. recurvus and $N$. canaliculatus (Miroslav et al., 2015).

\section{Essential oils}

\section{What is an essential oil?}

Essential oils are a complex mixture of natural compounds obtained mainly from plants or herbs. The physical properties of essential oils are they appear as a colored mixture of several aromatic compounds, liquid and volatile (Macwan et al., 2016). The ultimate role of essential oils is to protect plants against any threat from the environment, such as pathogens and insects that act as plug vectors. Therefore, they are well-known for their medicinal properties such as antiseptic, anti-carcinogenic, antiinflammatory, analgesic, anesthetic and they are mainly used as natural additives in food and food products due to their antioxidant and antimicrobial properties.

\section{Phytochemical compounds of essential oils}

The chemicals composition of essential oils is affected by several factors such as plant species, method of extraction, geography and environment. Different location has a different composition of the chemical compounds of essential oil due to climate differences, humidity which constitute different species of insect or microbial properties that induce the plant to produce its own phytochemicals. Terpenes ( $p$-cymene, limonene, terpinene, sabinene and $\alpha$ - and $\beta$-pinene) and terpenoids (thymol, carvacrol, linalyl acetate, linalool, piperitone, citronellal, geraniol and menthol Figure 7) are the main categories of compounds in essential oil fairly at high concentration (20-70\%) (Niu and Gilbert, 2004).

\section{Mechanisms of action}

\section{i. Cell membrane disruption}

The fungal cell wall consists of essential elements such as glucan, chitin and mannan for fungal survival. Phytochemicals in essential oils affect fungal cell wall maturation, septum formation and bud ring formation (Wu et al., 2008). This leads to the thinning and distortion of the hyphal wall, thus causing the hyphal tip to be divided into bud-like structure. The severity of damage can be up to the level where the cytoplasm leakage inhibits DNA, RNA, protein and peptidoglycan biosynthesis and, lastly, inhibits the ergosterol biosynthesis (Nazzaro et al., 2017). Anise oil manifests antifungal activity against filamentous fungus by its trans-anethole that inhibits chitin synthase activity in permeabilized hyphae (Yutani et al., 2011). Another example of cell membrane disruption is by the essential oil extracted from Citrus sinensis epicarp that contains almost $85 \%$ limonene. This essential oil leads to the irreversible deleterious morphological alteration that is capable of inhibiting the growth of Aspergillus niger (Sharma and Tripathi, 2008). A similar effect is exhibited by thymoquinone, a component of black cumin seed essential oil that extensively damages the fungal cell wall and cytoplasmic membrane (İşcan et al., 2016).

\section{ii. Dysfunction of fungi mitochondria}

Essential oils can inhibit mitochondrial dehydrogenase systems responsible for biosynthesis of ATP such as lactate dehydrogenase, malate dehydrogenase and succinate dehydrogenase. For example, Anethum graveolens essential oil was capable of inhibiting Candida albicans's ATP biosynthesis and at the same time disturbed the citric acid cycle (Chen et al., 2013). Other essential oils that were extracted from various plants such as Origanum compactum, Artemisia herba alba and Cinnamomum camphora also shows mitochondrial damage when treated to Saccharomyces cerevisiae. The antifungal activity of essential oil towards mitochondrial damage was comprehended to be the role of terpenoids that give rise to an altered level of reactive oxygen species and ATP generation (Haque et al., 2016).

\section{iii. Inhibition of efflux pumps}

The physiology of fungi such as the electrochemical proton gradient across the cell membrane for nutrient uptake, intracellular $\mathrm{pH}$, fungal growth, and fungal pathogenicity were all supported by fungal plasma membrane $\mathrm{H}^{+}$-ATPase (Haque et al., 2016). Apart from that, the fungal plasma membrane also regulates nutrient uptake and medium acidification (Perlin et al., 1997). Therefore, inhibition of $\mathrm{H}^{+}$-ATPase leads to intracellular acidification and cell death. Thyme oil exhibits the overexpression of the efflux-pump gene. The chemical components that play a role in the inhibition of the overexpression of efflux-pump genes CDR1 and MDR1 in C. albicans are thymol and carvacrol and the reaction is located at the membrane level (Nazzaro et al., 2017).

\section{Antifungal activities of essential oils}

The presence of fungal infection is more difficult to verify and difficult to treat and eliminate as compared to bacterial infection. The inception and acuteness of fungal infection depend on the host's resistance and inoculum charge. The synthetic antimicrobial treatment of fungal infection is effective, but in the long term, it will generate resistant fungal species and caused side effects on the organ (liver and kidney) functionality (Williams and Lewis, 2011). Due to apprehension on the safety of synthetic antimicrobial agents, the limelight has been diverted to the potential application of essential oil as an alternative 


\section{Terpenes}<smiles>Cc1ccc(C(C)C)cc1</smiles><smiles>C=C(C)C1CC=C(C)CC1</smiles>

Limonene<smiles>Cc1ccc(C(C)C)cc1O</smiles>

Carvacrol<smiles>CC1=CC(=O)C(C(C)C)CC1</smiles><smiles>CC1=CC(=O)C(C(C)C)=CC1=O</smiles>

Menthol<smiles>CC1=CC[C@@H]2C[C@H]1C2(C)C</smiles>

$\alpha$ - pinene

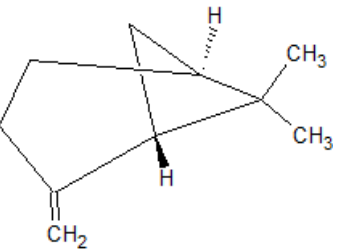

$\beta$-pinene<smiles>CC1=CCC(C(C)C)=CC1</smiles>

Terpinene

\section{Terpenoid}<smiles>Cc1ccc(C(C)C)c(O)c1</smiles>

Thymol<smiles>CC(C)=CCCC(C)=CCO</smiles>

Linalyl acetate<smiles>C=CC(C)(O)CCC=C(C)C</smiles>

Linalool

Geraniol<smiles>CC(C)=CCCC(C)CC=O</smiles>

Citronellal

Figure 7: Structures of terpenes and terpenoids reported in this review. 
treatment for fungal infection. Essential oils have a broad spectrum of antifungal properties and are environmentally friendly (no non-toxic residue and by-product). The antifungal activity of essential oil is highly due to the existence of terpenes/terpenoid and the lipophilic properties that enable disruption of the cell wall and membranes and organelles of the fungal cell and/or inhibit nuclear material or protein synthesis that leads to death of
fungi
(Figure
(Tian
et
al., 2011)

List of essential oils with antifungal effect

Many essential oils are now known to contain powerful antifungal properties and the following list is not exhaustive but representative of those commonly believed to be the best treatment for fungal infections and scientifically proven to possess antifungal qualities (Table 2).

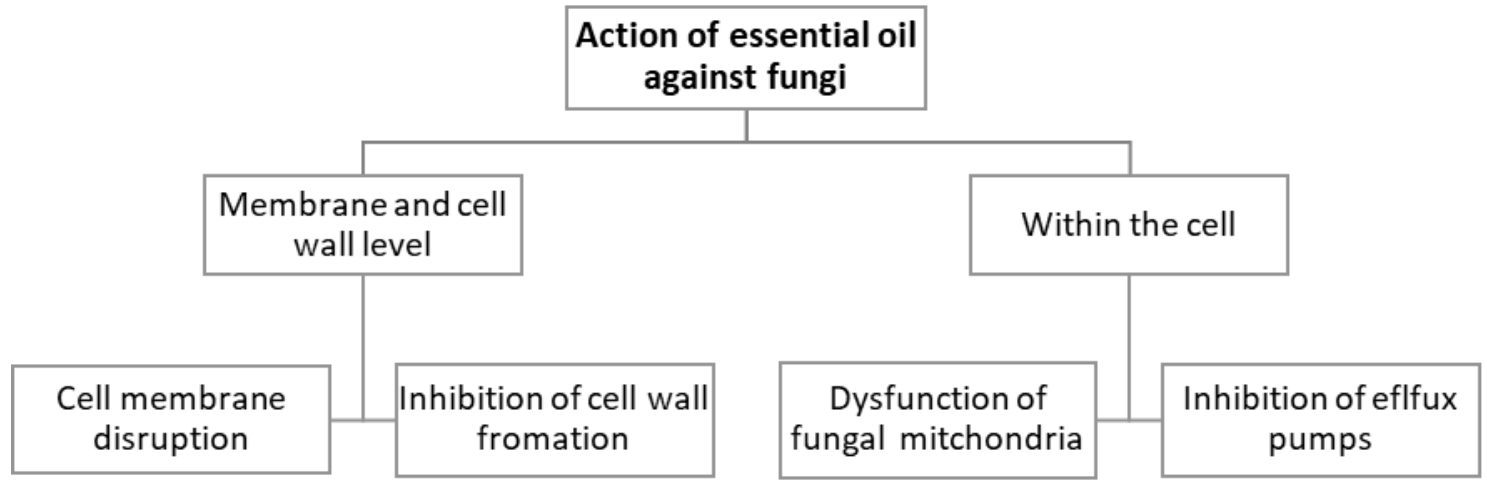

Figure 8: Antifungal activities of essential oils towards fungi.

Table 2: List of potential essential oil for antifungal treatment.

\begin{tabular}{|c|c|c|c|}
\hline Name of plants & Biochemical compound & Antifungal activity & Reference \\
\hline $\begin{array}{l}\text { Stems of Croton } \\
\text { tricolor }\end{array}$ & $\begin{array}{l}\text { Epiglobulol, } \alpha \text {-bisabolol, } \alpha- \\
\text { trans-bergamotol and } \beta \text { - } \\
\text { caryophyllene }\end{array}$ & $\begin{array}{l}\text { Candida species; C. albicans (ATCC 90028), } \\
\text { C. albicans (LM105), C. tropicalis (ATCC } \\
\text { 13,803), C. tropicalis (LM 14), C. krusei } \\
(\text { ATCC 6538) and C. krusei (LM 12) }\end{array}$ & $\begin{array}{l}\text { (Huang et al., } \\
2019)\end{array}$ \\
\hline Polyscias fulva & $\begin{array}{l}\text { Saponins, } \quad \text { tannins, } \\
\text { alkaloids, anthraquinone } \\
\text { and phenols }\end{array}$ & $\begin{array}{l}\text { M. audouinii, } T . \text { rubrum, } T . \text { ajelloi, } T . \\
\text { equinum, T. mentagrophytes, } T . \text { terrestre, } M . \\
\text { gypseum and E. floccosum }\end{array}$ & $\begin{array}{l}\text { (Njateng et al., } \\
\text { 2013) }\end{array}$ \\
\hline Ferulago capillaris & Limonene and $\alpha$-pinene & $\begin{array}{l}\text { Candida, Cryptococcus, Aspergillus and } \\
\text { dermatophyte strains }\end{array}$ & $\begin{array}{l}\text { (Pinto et al., } \\
\text { 2013) }\end{array}$ \\
\hline Moringa oleifera Lam & $\begin{array}{l}\text { Pentacosane } \\
\text { hexacosane }\end{array}$ & $\begin{array}{l}T . \text { rubrum, T. mentagrophytes, E. floccosum } \\
\text { and } M . \text { canis }\end{array}$ & $\begin{array}{l}\text { (Chuang et al., } \\
\text { 2007) }\end{array}$ \\
\hline Allium sativum & $\begin{array}{l}\text { Di-2-propenyl trisulfide and } \\
\text { di-2-propenyl disulfide }\end{array}$ & T. erinacei, T. rubrum, and T. soudanense & $\begin{array}{l}\text { (Pyun and Shin, } \\
\text { 2006) }\end{array}$ \\
\hline Curcuma longa & $\begin{array}{l}\text { Turmerone, atlantone, and } \\
\text { zingiberone }\end{array}$ & $\begin{array}{l}\text { T. mentagrophytes, T. rubrum, E. floccosum, } \\
\text { and M. gypseum }\end{array}$ & $\begin{array}{l}\text { (Jankasem et al., } \\
\text { 2013) }\end{array}$ \\
\hline Eugenia cariophyllata & Eugenol & $\begin{array}{l}\text { C. albicans, C. tropicalis, C. krusei, } T . \\
\text { rubrum, T. mentagrophytes and Geotrichum } \\
\text { candidum }\end{array}$ & $\begin{array}{l}\text { (Gayoso et al., } \\
\text { 2005) }\end{array}$ \\
\hline $\begin{array}{l}\text { Salvia cryptantha } \\
\text { and S. multicaulis }\end{array}$ & $\begin{array}{l}\text { a-pinene, eucalyptol, } \\
\text { camphor, camphene and } \\
\text { borneol }\end{array}$ & C. albicans and C. krusei & $\begin{array}{l}\text { (Tepe et al., } \\
\text { 2004) }\end{array}$ \\
\hline
\end{tabular}




\section{Antifungal peptides}

\section{What are antifungal peptides?}

Antifungal peptides (AFP) are small cationic, amphipathic molecules with less than 50 amino acids isolated from plants, animals, bacteria and fungi (Matejuk et al., 2010). AFP is a cysteine-rich protein that encodes various AFP that belong to different classes (Garrigues et al., 2018). With confine requirement for commercialization, AFP prominently meets the desired criteria to be a commercial antifungal. Firstly, it is highly stable toward high temperatures, proteolysis, as well as acidic condition (Dorsaz et al., 2017). In nature, antimicrobial and antifungal peptides are the first-line defense for any organism against a wide spectrum of microbe infection that has no toxic effect towards the host organism (Matejuk et al., 2010). Evidence suggests that the antifungal activity of antimicrobial peptides (AMPs) is multifactorial. The modulation of the immune system and the host immune status determine the efficacy of the peptide likely similar to other antifungal agents (Ben-Ami et al., 2008).

\section{Mechanism of action}

There are two modes of the mechanism of action of AFP; the first one is through permeabilization of the cell membrane, which may break down into two mode of actions. The first one is the carpet model, where protein molecules insert into the membrane and forming pores. The second one is the pore model, where the protein molecules oligomerize and form a multimeric pore (Brogden, 2005). Both models are based on AFP bacterial interaction, where the cationic character of defensins interacts with the negatively charged plasma membrane of bacteria. What follows is the disintegration of the plasma membrane and cell leakage and cell death (necrosis). Another mode of the mechanism of action of AFP is where the membrane interaction may not primarily damage the plasma membrane, but the interaction with specific lipid or protein components of the plasma membrane caused the formation of a transient pore. The interaction resulted in the protein transport into the host cell and interacted with the intracellular target. This led to an increase in the cellular level of reactive oxygen species (ROS) and triggered programmed cell death (Brogden, 2005).

\section{Classification and antifungal activity of peptides}

Antifungal peptides can be classified into two groups based on their mechanism of action, which are lysis and cell wall synthesis interference (Figure 9). Lytic peptides have the characteristic of amphipathic. Amphipathic molecules possess a polar and non-polar region that is hydrophilic and hydrophobic, respectively. The lytic antifungal peptide can bind to the cell membrane and disrupt the membrane structure without traversing, or it is able to traverse the cell membrane and interact with specific intracellular molecules. Some lytic peptides form an aqueous pore allowing transposes of ions and other solutes (De Lucca and Walsh, 1999).

Initial effort to commercialize antimicrobial peptides (AMP) was unsuccessful due to the complex biology and pleiotropic nature of AMP that was not fully understood (Duncan and O'Neil, 2013). Another difficulty for the commercialization of AMP is their biological instability. AMP is more susceptible to proteolytic degradation in the systemic environment that resulted in a shorter half-life of AMP, thus making it unable to maintain plasma concentration needed for their minimal inhibitory concentration (Duncan and O'Neil, 2013). There is a need to develop AMP molecules that retain their positive

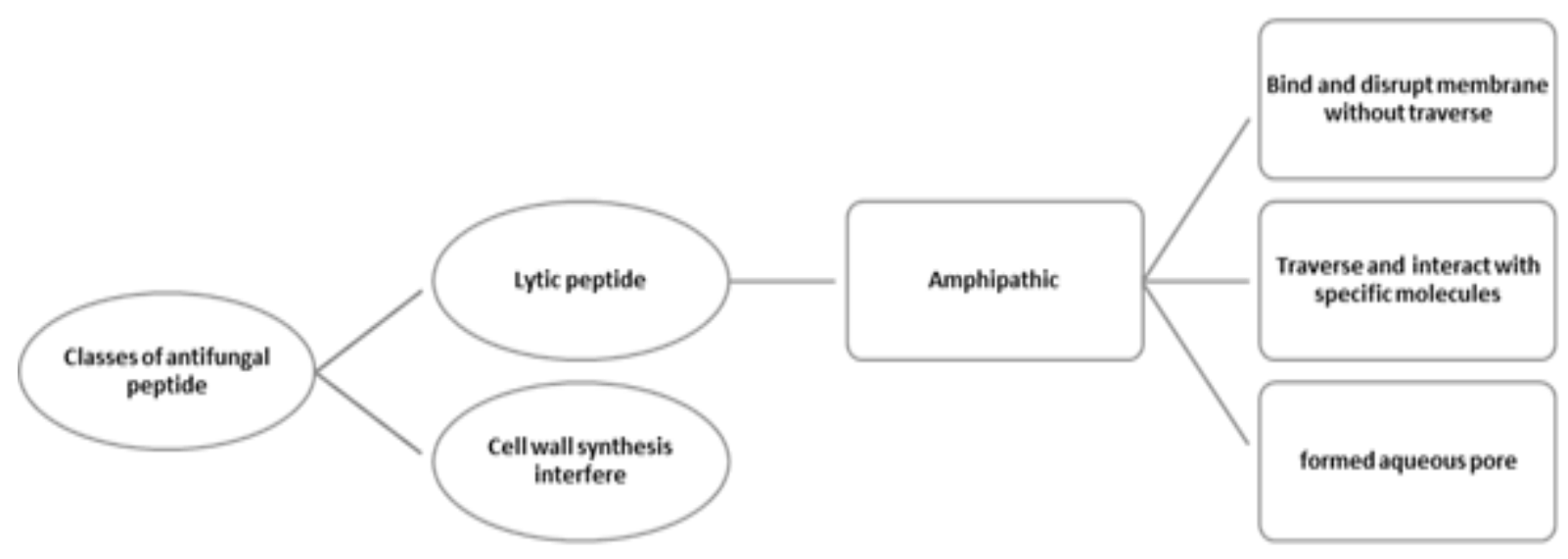

Figure 9: Classification of antifungal peptides. 
physiochemical functions but devoid of the negative features such as hemolytic and inflammatory potential that previously held back their translation into the clinical stage (Ahmad et al., 1995). The ability to kill yeast, hyphae, spores and the charge-dependent fungicidal that minimizes the chance of resistance are all attractive therapeutic features of the engineered antifungal peptide (Muralidharan and Bobek, 2005). Meanwhile, the recent technology on control released polymer system that introduces the nanoparticle encapsulation, liposomal delivery and PEGylation are the new ways to tackle the instability problem of AMP that enable it to be commercialized (Duncan and O'Neil, 2013).

Among the wide groups of AMP, defensins are the most outstanding AMP, which have a close structural relationship that generally exists in plants, insects and mammals. Defensins generally contain six to eight cysteine from intramolecular disulfide bond and stabilized with an anti-parallel $\beta$-sheet conformation and enclosed with an $\alpha$-helical segment (Bulet and Stocklin, 2005). The resistance toward extreme conditions like $\mathrm{pH}$, temperature and protease-mediated degradation is due to the compact structure of defensins (Hegedüs and Marx, 2013).

\section{CONCLUSION}

A wide number of metabolites from plants and other natural sources have been reported to inhibit pathogenic fungi. These compounds represent a wide variety of structural classes ranging from terpenes, saponins, alkaloids, coumarins to peptides and proteins. The increasing number of multidrug-resistant strains of fungus makes it necessary to discover new classes of antifungal compounds to overcome fungal resistance mechanisms. This has led to a search for therapeutic alternatives, particularly medicinal plants and compounds isolated from them, to be used for antifungal properties. Another challenge is the small number of drugs available in the market due to the strict regulation and complex procedure of clinical trials for potential candidate compounds. From this review, various types of plant-based antifungal compounds against different fungi were identified and discussed. Likewise, some studies demonstrated the correlation between these natural compounds and their antifungal mechanisms of action. There are two major types of mechanisms of action, which are cell membrane disruption mode and interaction with intracellular molecules mode, which lead to programmed cell death. It is somehow challenging to simplify the mechanisms of action in plant secondary metabolites because many compounds exhibit their potency via more than one mechanism. Therefore, it is vital to have an in-depth examination of the compounds subgroups instead of grouping the metabolites into the biosynthetic group. The interference of the cell's nucleic acid and protein synthesis could be used as a new drug target provided that there is no damaging effects and/or interactions with the human system. Moreover, the efflux pump inhibition is foreseen to be significant in antifungal resistant strains in the future.

\section{CONFLICT OF INTEREST}

Authors declare no conflict of interest in this project.

\section{REFERENCES}

Abdel-Massih, R. M., Fares, R., Bazzi, S., El-Chami, N., and Baydoun, E. (2010). The apoptotic and antiproliferative activity of Origanum majorana extracts on human leukemic cell line. Leukemia Research 34(8), 1052-1056.

Ahmad, A., Wani, M. Y., Khan, A., Manzoor, N. and Molepo, J. (2015). Synergistic interactions of eugenolTosylate and its congeners with fluconazole against candida albicans. PLOS ONE 10(12), 1-19.

Ahmad, I., Perkins, W. R., Lupan, D. M., Selsted, M. E. and Janoff, A. S. (1995). Liposomal entrapment of the neutrophil-derived peptide indolicidin endows it with in vivo antifungal activity. Biochimica et Biophysica Acta (BBA)-Biomembranes 1237(2), 109-114.

Alves, C. T., Ferreira, I. C. F. R., Barros, L., Silva, S., Azeredo, J. and Henriques, M. (2014). Antifungal activity of phenolic compounds identified in flowers from North Eastern Portugal against Candida species. Future Microbiology 9(2), 139-146.

Arif, T., Bhosale, J. D., Kumar, N., Mandal, T. K., Bendre, R. S., Lavekar, G. S. and Dabur, R. (2009). Natural products - antifungal agents derived from plants. Journal of Asian Natural Products Research 11(7), 621-638.

Balasundram, N., Sundram, K. and Samman, S. (2006). Phenolic compounds in plants and agri-industrial byproducts: Antioxidant activity, occurrence, and potential uses. Food Chemistry 99(1), 191-203.

Baxi, S. N., Portnoy, J. M., Larenas-Linnemann, D. and Phipatanakul, W. (2016). Clinical commentary review exposure and health effects of fungi on humans. The Journal of Allergy and Clinical Immunology: In Practice 4(3), 396-404.

Ben-Ami, R., Lewis, R. E. and Kontoyiannis, D. P. (2008). Immunocompromised hosts: Immunopharmacology of modern antifungals. Clinical Infectious Diseases: An Official Publication of the Infectious Diseases Society of America 47(2), 226235.

Bone, K. and Mills, S. (2013). Principles of herbal pharmacology. In: Principles and Practice of Phytotherapy. Modern Herbal Medicine. Bone, K. and Mills, S. (eds.). $2^{\text {nd }}$ edn. Churchill Livingstone, New York, USA. pp. 17-82.

Borges, A., Ferreira, C., Saavedra, M. J. and Simões, M. (2013). Antibacterial activity and mode of action of ferulic and gallic acids against pathogenic bacteria. Microbial Drug Resistance 19(4), 256-265.

Brogden, K. A. (2005). Antimicrobial peptides: Pore formers or metabolic inhibitors in bacteria? Nature Reviews Microbiology 3(3), 238-250.

Bulet, P. and Stocklin, R. (2005). Insect antimicrobial 
peptides: Structures, properties and gene regulation. Protein and Peptide Letters 12(1), 3-11.

Burik, J. H. and Magee, P. T. (2001). Aspects of fungal pathogenesis in humans. Annual Reviews in Microbiology 55, 743-772.

Campoy, S. and Adrio, J. L. (2017). Antifungals. Biochemical Pharmacology 133, 86-96.

Carvalho, R. S., Carollo, C. A., de Magalhães, J. C., Palumbo, J. M. C., Boaretto, A. G., Nunes e Sá, I. C., Ferraz, A. C., Lima, W. G., de Siqueira, J. M. and Ferreira, J. M. S. (2018). Antibacterial and antifungal activities of phenolic compound-enriched ethyl acetate fraction from Cochlospermum regium (mart. Et. Schr.) Pilger roots: Mechanisms of action and synergism with tannin and gallic acid. South African Journal of Botany 114, 181-187.

Chandra, J., Kuhn, D. M., Mukherjee, P. K., Hoyer, L. L., McCormick, T. and Ghannoum, M. A. (2001). Biofilm formation by the fungal pathogen Candida albicans: Development, architecture, and drug resistance. Journal of Bacteriology 183(18), 53855394.

Cheah, H. L., Lim, V. and Sandai, D. (2014). Inhibitors of the glyoxylate cycle enzyme ICL1 in Candida albicans for potential use as antifungal agents. PLOS ONE 9(4), e95951.

Chen, Y., Zeng, H., Tian, J., Ban, X., Ma, B. and Wang, Y. (2013). Antifungal mechanism of essential oil from Anethum graveolens seeds against Candida albicans. Journal of Medical Microbiology 62(8), 1175-1183.

Chuang, P.-H., Lee, C.-W., Chou, J.-Y., Murugan, M., Shieh, B.-J. and Chen, H.-M. (2007). Anti-fungal activity of crude extracts and essential oil of Moringa oleifera Lam. Bioresource Technology 98(1), 232-236.

Da, X., Yamamoto, O., Tie, D., Hein, K. Z., Morita, E. and Nishiyama, Y. (2019). Antifungal activity and mechanism of action of Ou-gon (Scutellaria root extract) components against pathogenic fungi. Scientific Reports 9(1), 1-12.

De Lucca, A. J. and Walsh, T. J. (1999). Antifungal peptides: Novel therapeutic compounds against emerging pathogens. Antimicrobial Agents and Chemotherapy 43(1), 1-11.

Dhamgaye, S., Devaux, F., Vandeputte, P., Khandelwal, N. K., Sanglard, D., Mukhopadhyay, G. and Prasad, R. (2014). Molecular mechanisms of action of herbal antifungal alkaloid berberine, in Candida albicans. PLOS ONE 9(8), e104554.

Dorsaz, S., Snaka, T., Favre-Godal, Q., Maudens, P., Boulens, N., Furrer, P., Ebrahimi, S. N., Hamburger, M., Allémann, E., Gindro, K. and Queiroz, E. F. (2017). Identification and mode of action of a plant natural product targeting human fungal pathogens. Antimicrobial Agents and Chemotherapy 61(9), e00829-17.

Douglas, L. J. (2003). Candida biofilms and their role in infection. Trends in Microbiology 11, pp. 30-36.

Duncan, V. M. S. and O'Neil, D. A. (2013). Commercialization of antifungal peptides. Fungal Biology Reviews 26(4), 156-165.
Feuer, G. (1974). The metabolism and biological actions of Coumarins. In: Progress in Medicinal Chemistry. Ellis, G. P. and West, G. B. (eds.). Vol. 10. Elsevier Inc., Netherlands. pp. 85-158.

Fox, E., and Nobile, C. (2013). The role of Candida albicans biofilms in human disease. In: Candida albicans: Symptoms, Causes and Treatment Options. Dietrich, L. A. and Friedmann, T. S. (eds.). Nova Science Publishers, USA. pp. 1-24.

Garrigues, S., Gandía, M., Castillo, L., Coca, M. A., Marx, F., Marcos, J. F. and Manzanares, P. (2018). Three antifungal proteins from Penicillium expansum: Different patterns of production and antifungal activity. Frontiers in Microbiology 9, 2370.

Gayoso, C. W., Lima, E. O., Oliveira, V. T., Pereira, F. O., Souza, E. L., Lima, I. O. and Navarro, D. F. (2005). Sensitivity of fungi isolated from onychomycosis to Eugenia cariophyllata essential oil and eugenol. Fitoterapia 76(2), 247-249.

Gulis, V., Kuehn, K. A. and Suberkropp, K. (2009). Fungi. In: Encyclopedia of Inland Waters. Likens, G. E. (ed.). Elsevier Inc., Netherlands. pp. 233-243.

Haque, E., Irfan, S., Kamil, M., Sheikh, S., Hasan, A., Ahmad, A., Lakshmi, V., Nazir, A and Mir, S. S. (2016). Terpenoids with antifungal activity trigger mitochondrial dysfunction in Saccharomyces cerevisiae. Microbiology 85(4), 436-443.

Hazekamp, A., Fischedick, J. T., Díez, M. L., Lubbe, A. and Ruhaak, R. L. (2010). Chemistry of Cannabis. In: Comprehensive Natural Products II Chemisrty and Biology. Mander, L. and Lui, H.-W. (eds.). Vol. 3. pp. 1033-1084.

Hegedüs, N. and Marx, F. (2013). Antifungal proteins: More than antimicrobials? Fungal Biology Reviews 26(4), 132-145.

Huang, F., Kong, J., Ju, J., Zhang, Y., Guo, Y., Cheng, Y., Qian, H., Xie, Y. and Yao, W. (2019). Membrane damage mechanism contributes to inhibition of transcinnamaldehyde on Penicillium italicum using SurfaceEnhanced Raman Spectroscopy (SERS). Scientific Reports 9(1), 1-10.

Huang, W.-Y., Cai, Y.-Z. and Zhang, Y. (2009). Natural phenolic compounds from medicinal herbs and dietary plants: Potential use for cancer prevention. Nutrition and Cancer 62(1), 1-20.

İşcan, G., İşcan, A. and Demirci, F. (2016). Anticandidal effects of thymoquinone: Mode of action determined by transmission electron microscopy (TEM). Natural Product Communications 11(7), 977-978.

Jankasem, M., Wuthi-udomlert, M. and Gritsanapan, W. (2013). Antidermatophytic properties of arturmerone, turmeric oil, and Curcuma longa preparations. ISRN Dermatology 250597.

Jia, C., Zhang, J., Yu, L., Wang, C., Yang, Y., Rong, X., $\mathrm{Xu}, \mathrm{K}$. and Chu, M. (2019). Antifungal activity of coumarin against Candida albicans is related to apoptosis. Frontiers in Cellular and Infection Microbiology 8, 445.

Jiang, X., Feng, K. and Yang, X. (2015). In vitro antifungal activity and mechanism of action of tea 
polyphenols and tea saponin against Rhizopus stolonifer. Journal of Molecular Microbiology and Biotechnology 25(4), 269-276.

Karkowska-kuleta, J., Rapala-kozik, M. and Kozik, A. (2009). Fungi pathogenic to humans: Molecular bases of virulence of Candida albicans, Cryptococcus neoformans and Aspergillus fumigatus. Acta Biochimica Polonica 56(2), 211-224.

Kaur, R. and Arora, S. (2015). Alkaloids-important therapeutic secondary metabolites of plant origin. Journal of Critical Reviews 2(3), 1-8.

Kozioł, E. and Skalicka-Woźniak, K. (2016). Imperatorin-pharmacological meaning and analytical clues: Profound investigation. Phytochemistry Reviews 15(4), 627-649.

Ludwiczuk, A., Skalicka-Woźniak, K., and Georgiev, M. I. (2017). Terpenoids. In: Pharmacognosy. Badal, S. and Delgoda, R. (eds.). Elsevier Inc., Netherland. pp. 233-266.

Macwan, S. R., Dabhi, B. K., Aparnathi, K. D. and Prajapati, J. B. (2016). Essential oils of herbs and spices: Their antimicrobial activity and application in preservation of food. International Journal of Current Microbiology and Applied Sciences 5(5), 885-901.

Martins, N., Barros, L., Henriques, M., Silva, S. and Ferreira, I. C. F. R. (2015). Activity of phenolic compounds from plant origin against Candida species. Industrial Crops and Products 74, 648-670.

Matejuk, A., Leng, Q., Begum, M. D., Woodle, M. C., Scaria, P., Chou, S. T. and Mixson, A. J. (2010). Peptide-based antifungal therapies against emerging infections. Drugs of the Future 35(3), 197.

Mbaveng, A. T., Hamm, R. and Kuete, V. (2014). Harmful and protective effects of terpenoids from african medicinal plants. In: Toxicological Survey of African Medicinal Plants. Kuete, V. (ed.). Elsevier. pp. 557-576.

Mert-Türk, F. (2006). Saponins versus plant fungal pathogens. Journal of Cell and Molecular Biology 5, 13-17.

Miroslav, L., Jitka, N., Pavel, K., Anna, H., Ladislav, K., Lucie, G., Marcela, S., Lubomír, $O$ and Lucie, C. (2015). Antifungal and antibacterial activity of extracts and alkaloids of selected Amaryllidaceae species. Natural Product Communications 10(9), 1537-1540.

Montagner, C., de Souza, S. M., Groposo, C., Delle Monache, F., Smânia, E. F. A. and Smânia Jr, A. (2008). Antifungal activity of coumarins. Zeitschrift Für Naturforschung C 63(1-2), 21-28.

Mshvildadze, V., Favel, A., Delmas, F., Elias, R., Faure, R., Decanosidze, G., Kemertelidze, E. and Balansard, G. (2000). Antifungal and antiprotozoal activities of saponins from Hedera colchica. Die Pharmazie 55(4), 325.

Muralidharan, R. and Bobek, L. A. (2005). Antifungal activity of human salivary mucin-derived peptide, MUC7 12-mer, in a murine model of oral candidiasis. The Journal of Peptide Research 66(Suppl 1), 82-89.

Nazzaro, F., Fratianni, F., Coppola, R. and Feo, V. De. (2017). Essential oils and antifungal activity.
Pharmaceuticals (Basel, Switzerland) 10(4), 1-20.

Niu, C. and Gilbert, E. S. (2004). Colorimetric method for identifying plant essential oil components that affect biofilm formation and structure. Applied and Environmental Microbiology 70(12), 6951-6956.

Njateng, G. S. S., Gatsing, D., Mouokeu, R. S., Lunga, P. K. and Kuiate, J.-R. (2013). In vitro and in vivo antidermatophytic activity of the dichloromethanemethanol $(1: 1 \mathrm{v} / \mathrm{v})$ extract from the stem bark of Polyscias fulva Hiern (Araliaceae). BMC Complementary and Alternative Medicine 13(1), 95.

Onishi, J., Meinz, M., Thompson, J., Curotto, J., Dreikorn, S., Rosenbach, M. et al. (2000). Discovery of novel antifungal $(1,3)$ - $\beta$-glucan synthase inhibitors. Antimicrobial Agents and Chemotherapy 44(2), 368377.

Perlin, D. S., Seto-Young, D. and Monk, B. C. (1997). The plasma membrane $\mathrm{H}(+)$-ATPase of fungi. A candidate drug target? Annals of the New York Academy of Sciences 834, 609-617.

Picman, A. K., Schneider, E. F. and Gershenzon, J. (1990). Antifungal activities of sunflower terpenoids. Biochemical Systematics and Ecology 18(5), 325-328.

Pinto, E., Hrimpeng, K., Lopes, G., Vaz, S., Gonçalves, M. J., Cavaleiro, C. and Salgueiro, L. (2013). Antifungal activity of Ferulago capillaris essential oil against Candida, Cryptococcus, Aspergillus and dermatophyte species. European Journal of Clinical Microbiology \& Infectious Diseases 32(10), 1311-1320.

Polacheck, I., Levy, M., Guizie, M., Zehavi, U., Naim, M. and Evron, R. (1991). Mode of action of the antimycotic agent $\mathrm{g} 2$ isolated from alfalfa roots. Zentralblatt Für Bakteriologie 275(4), 504-512.

Porsche, F. M., Molitor, D., Beyer, M., Charton, S., André, C. and Kollar, A. (2017). Antifungal activity of saponins from the fruit pericarp of Sapindus mukorossi against Venturia inaequalis and Botrytis cinerea. Plant Disease 102(5), 991-1000.

Pyun, M.-S. and Shin, S. (2006). Antifungal effects of the volatile oils from Allium plants against Trichophyton species and synergism of the oils with ketoconazole. Phytomedicine 13(6), 394-400.

Rao, A., Zhang, Y., Muend, S. and Rao, R. (2010). Mechanism of antifungal activity of terpenoid phenols resembles calcium stress and inhibition of the TOR pathway. Antimicrobial Agents and Chemotherapy 54(12), 5062-5069.

Sales, M. D. C., Costa, H. B., Fernandes, P. M. B., Ventura, J. A. and Meira, D. D. (2016). Antifungal activity of plant extracts with potential to control plant pathogens in pineapple. Asian Pacific Journal of Tropical Biomedicine 6(1), 26-31.

Sharma, N. and Tripathi, A. (2008). Effects of Citrus sinensis (L.) Osbeck epicarp essential oil on growth and morphogenesis of Aspergillus niger (L.) Van Tieghem. Microbiological Research 163(3), 337-344.

Shi, J., Yu, J., Pohorly, J. E. and Kakuda, Y. (2003). Polyphenolics in grape seeds-biochemistry and functionality. Journal of Medicinal Food 6(4), 291-299.

Singh, A. K., Pandey, M. B. and Singh, U. P. (2007). 
Antifungal activity of an alkaloid allosecurinine against some fungi. Mycobiology 35(2), 62-64.

Sofowora, A., Ogunbodede, E. and Onayade, A. (2013). The role and place of medicinal plants in the strategies for disease prevention. African Journal of Traditional, Complementary, and Alternative Medicines: AJTCAM / African Networks on Ethnomedicines 10(5), 210-229.

Srinivasan, S. and Sarada, D. V. L. (2012). Antifungal activity of phenyl derivative of pyranocoumarin from Psoralea corylifolia L. seeds by inhibition of acetylation activity of trichothecene 3-O-acetyltransferase (Tri101). Journal of Biomedicine and Biotechnology 310850.

Tang, H. Q., Hu, J., Yang, L. and Tan, R. X. (2000). Terpenoids and flavonoids from Artemisia species. Planta Medica 66(04), 391-393.

Tepe, B., Donmez, E., Unlu, M., Candan, F., Daferera, D., Vardar-Unlu, G., Polissiou, M. and Sokmen, A. (2004). Antimicrobial and antioxidative activities of the essential oils and methanol extracts of Salvia cryptantha (Montbret et Aucher ex Benth.) and Salvia multicaulis (Vahl). Food Chemistry 84(4), 519-525.

Thoppil, R. J. and Bishayee, A. (2011). Terpenoids as potential chemopreventive and therapeutic agents in liver cancer. World Journal of Hepatology 3(9), 228249.

Tian, J., Ban, X., Zeng, H., He, J., Huang, B. and Wang, Y. (2011). Chemical composition and antifungal activity of essential oil from Cicuta virosa L. var. latisecta Celak. International Journal of Food Microbiology 145(2-3), 464-470.

Tomasz Kubrak, T., Rafał Podgórski, R. and Monika Sompor, M. (2017). Natural and synthetic coumarins and their pharmacological activity. European Journal of Clinical and Experimental Medicine 15(2), 169-175.

Tripathi, S. K., Xu, T., Feng, Q., Avula, B., Shi, X., Pan, X., Mask, M. M., Baerson, S. R., Jacob, M. R., Ravu, R. R. and Khan, S. I. (2017). Two plant-derived aporphinoid alkaloids exert their antifungal activity by disrupting mitochondrial iron-sulfur cluster biosynthesis. Journal of Biological Chemistry 292(40), 16578-16593.

Tsuzuki, J. K., Svidzinski, T. I. E., Shinobu, C. S., Silva, L. F. A., Rodrigues-Filho, E., Cortez, D. A. G. and Ferreira, I. C. P. (2007). Antifungal activity of the extracts and saponins from Sapindus saponaria L. Anais Da Academia Brasileira de Ciencias 79(4), 577. 583.

Uppuluri, P. and Lopez Ribot, J. L. (2017). Candida albicans biofilms. In: Candida albicans: Cellular and Molecular Biology. Prasad, R. (eds). $2^{\text {nd }}$ edn. Springer, Cham. pp. 63-75.

Venugopala, K. N., Rashmi, V. and Odhav, B. (2013). Review on natural coumarin lead compounds for their pharmacological activity. BioMed Research International 2013, 1-14.

Wang, W., Cheng, M. H. and Wang, X. H. (2013). Monoterpenoid indole alkaloids from Alstonia rupestris with cytotoxic, anti-inflammatory and antifungal activities. Molecules 18(6), 7309-7322.

Wang, X.-G., Wei, X.-Y., Tian, Y.-Q., Shen, L.-T. and Xu, H.-H. (2010). Antifungal flavonoids from Ficus sarmentosa var. henryi (King) Corner. Agricultural Sciences in China 9(5), 690-694.

Webster, D., Taschereau, P., Belland, R. J., Sand, C. and Rennie, R. P. (2008). Antifungal activity of medicinal plant extracts; preliminary screening studies. Journal of Ethnopharmacology 115(1), 140-146.

Williams, D. and Lewis, M. (2011). Pathogenesis and treatment of oral candidosis. Journal of Oral Microbiology 3(1), 5771.

Wu, X., Cheng, A., Sun, L. and Lou, H. (2008). Effect of plagiochin $\mathrm{E}$, an antifungal macrocyclic bis (bibenzyl), on cell wall chitin synthesis in Candida albicans. Acta Pharmacologica Sinica 29(12), 1478-1485.

Yang, L., Liu, X., Zhuang, X., Feng, X., Zhong, L. and Ma, T. (2018). Antifungal effects of saponin extract from rhizomes of Dioscorea panthaica Prain et Burk against Candida albicans. Evidence-Based Complementary and Alternative Medicine 2018, Article ID 6095307.

Yutani, M., Hashimoto, Y., Ogita, A., Kubo, I., Tanaka, T. and Fujita, K. (2011). Morphological changes of the filamentous fungus Mucor mucedo and inhibition of chitin synthase activity induced by anethole. Phytotherapy Research 25(11), 1707-1713.

Zabka, M. and Pavela, R. (2013). Antifungal efficacy of some natural phenolic compounds against significant pathogenic and toxinogenic filamentous fungi. Chemosphere 93(6), 1051-1056.

Zhang, J. D., Zheng, X., Yong-Bing, C., Hai-Sheng, C., Lan, Y., Mao-Mao, A., Ping-Hui, G., Yan, W., XinMing, J. and Yuan-Ying, J. (2006). Antifungal activities and action mechanisms of compounds from Tribulus terrestris L. Journal of Ethnopharmacology 103, 76-84. 